\title{
PENINGKATAN KEMAMPUAN MENULIS KARANGAN DESKRIPSI MENGGUNAKAN METODE FIELD TRIP PADA MATA PELAJARAN BAHASA INDONESIA SISWA KELAS IV SD NEGERI DADAPSARI
}

\author{
Kholifaturrahmah, Amaliyah Ulfah \\ Universitas Ahmad Dahlan \\ olifarahma@gmail.com
}

\begin{abstract}
Teacher teaching methods that are less varied in Indonesian language learning cause, the low value of the ability to write student description essays. The purpose of this study was to improve the ability to write a description essay using the field trip method for fourth grade students of SD Negeri Dadapsari Sleman. This research is a Classroom Action research, with 2 cycles of action. The subjects in this study were the fourth grade students of SD Negeri Dadapsari which numbered 20 students, while the objects in this study were the ability to write a description essay. Data collection techniques were in the form of observation, tests and documentation. The research instrument consisted of observation sheets and essay test sheets. The analysis technique used is descriptive and quantitative data analysis. The results showed that field trip methods can improve the ability to write description essays. This is confirmed by; 1) Field trip methods have been shown to increase student enthusiasm and student activity, with the material provided and supported by the environment making students curiosity emerge. 2) From the results of the study it can be shown that there is an increase in the ability to write description essays, namely an increase in the first cycle of the first meeting, there are 5 students with a percentage (25\%), then increasing in the second meeting there are 8 students with a percentage $(40 \%)$ who obtain complete grades. While the results of the ability to write an essay description in the second cycle of the first meeting there were 14 students with a percentage (70\%) who got the complete score, for the second meeting there were 18 students with a percentage (90\%) of students who received complete grades. The results of the percentage show that the ability to write student description essays can be increased by applying the field trip method.
\end{abstract}

Keywords: ability, writing, description essay, field trip

\begin{abstract}
ABSTRAK
Metode mengajar guru yang kurang bervariasi dalam pembelajaran bahasa Indonesia menyebabkan, rendahnya nilai kemampuan menulis karangan deskripsi siswa. Tujuan penelitian ini untuk meningkatkan kemampuan menulis karangan deskripsi menggunakan metode field trip pada siswa kelas IV SD Negeri Dadapsari Sleman. Penelitian ini merupakan penelitian Tindakan Kelas, dengan tindakan sebanyak 2 siklus. Subjek dalam penelitian ini adalah siswa kelas IV SD Negeri Dadapsari yang berjumlah 20 siswa, sedangkan objek dalam penelitian ini adalah kemampuan menulis karangan deskripsi.teknik pengumpulan data berupa observasi,tes dan dokumentasi. Instrumen penelitian ini terdiri dari lembar observasi dan lembar tes karangan. Teknik analisis yang digunakan yaitu analisis data deskriptif dan kuantitatif. Hasil penelitian menunjukkan
\end{abstract}


bahwa metode field trip dapat meningkatkan kemampuan menulis karangan deskripsi. Hal ini dibukutikan dengan; 1) Metode field trip terbukti membuat antusias siswa dan aktivitas siswa meningkat, dengan materi yang diberikan dan didukung dengan lingkungan membuat rasa ingin tahu siswa muncul. 2) Dari hasil penelitian dapat ditunjukkan adanya peningkatan kemampuan menulis karangan deskripsi yakni peningkatan pada siklus I pertemuan pertama terdapat 5 siswa dengan presentase $(25 \%)$, kemudian meningkat pada pertemuan kedua terdapat 8 siswa dengan presentase (40\%) yang memperoleh nilai tuntas. Sedangkan hasil kemampuan menulis karangan deskripsi pada siklus II pertemuan pertama terdapat 14 siswa dengan presentase $(70 \%)$ yang mendapatkan nilai tuntas, untuk pertemuan kedua terdapat 18 siswa dengan presentase (90\%) siswa yang memperoleh nilai tuntas. Dari hasil presentase menujukkan bahwa kemampuan menulis karangan deskripsi siswa dapat meningkat dengan menerapkan metode field trip.

Kata kunci: kemampuan, menulis, karangan deskripsi, field trip

\section{PENDAHULUAN}

Mata pelajaran Bahasa Indonesia merupakan salah satu mata pelajaran yang wajib diajarkan di SD. Pembelajaran bahasa Indonesia ditekankan pada empat keterampilan, yaitu keterampilan menyimak, berbicara, membaca dan menulis. Keterampilan menyimak dan berbicara merupakan komunikasi secara langsung, sedangkan keterampilan membaca dan menulis merupakan komunikasi secara tidak langsung. Keempat keterampilan tersebut disajikan secara terpadu, tetapi dapat ditekankan pada keterampilan menulis. Keterampilan menulis adalah keterampilan yang paling akhir diajarkan setelah keterampilan menyimak, berbicara dan membaca. Dalam hal ini penekanan yang lebih besar perlu dilakukan karena dalam menulis siswa dituntut untuk berpikir kreatif mengungkapkan pikiran, ide dan gagasan. Dalam kegiatan menulis, ide dituangkan dalam bentuk kata-kata yang harus disusun menjadi suatu kalimat, kalimat demi kalimat disusun lagi dalam sebuah paragraf, kemudian paragraf demi paragraf disusun menjadi sebuah tulisan yang utuh. Tulisan yang utuh tersebut dikenal dengan karangan. Dalam karangan, hubungan kata demi kata, kalimat demi kalimat dan paragraf demi paragraf harus berhubungan agar dimengerti oleh pembaca.

Pembelajaran keterampilan menulis di SD dalam pengembangannya siswa perlu dikenalkan dengan berbagai jenis karangan. Jenis karangan tersebut antara lain: karangan deskriptif, karangan narasi, karangan persuasi, karangan eskposisi dan karangan argumentasi. Menurut Daeng Nurjamal (2014) karangan deskriptif yaitu tulisan yang berisi gambaran tentang suatu objek atau keadaan tertentu yang dijelaskan seolah-olah objek tersebut terlihat. Dengan mempelajari berbagai jenis karangan, siswa diharapkan mampu menuangkan pikiran, ide dan gagasan sesuai dengan perintah atau sesuai dengan jenis karangan. Melalui latihan menulis secara bertahap, diharapkan dapat membangun keterampilan menulis siswa agar lebih meningkat lagi. Kegiatan menulis dalam dunia persekolahan termasuk dalam aktivitas pembelajaran yang memperhatinkan. Selama ini pembelajaran menulis dilakukan secara konvensional. Artinya siswa diberi sebuah teori menulis karangan kemudian siswa melihat contoh dan akhirnya siswa ditugasi untuk membuat karangan secara baik. Kesimpulan tersebut diperkuat dengan adanya fakta bahwa media atau sumber belajar yang variatif tidak di munculkan oleh guru. Sumber belajar diluar guru yang dapat dimanfaatkan oleh siswa yaitu buku teks dan LKS. Oleh karena itu, suasana belajar mengajar menjadi membosankan dan siswa merasa jenuh mengikuti proses pembelajaran tersebut. Selain itu, siswa belum mampu mengidentifikasikan sebuah peristiwa ataupun gambaran yang ada dalam pikiran masing-masing untuk dirangkai ke 
dalam bentuk tulisan atau dalam kata lain siswa kurang dapat menggali ide dan gagasan. Padahal guru sudah menentukan tema tulisan secara jelas.

Masalah yang saat ini terjadi dalam pembelajaran menulis di sekolah khususnya SD Negeri Dadapsari berdasarkan hasil observasi yang dilakukan pada saat bulan April 2018, yaitu dengan guru wali kelas IV menunjukkan rendahnya kualitas nilai keterampilan menulis siswa. Perolehan nilai seharusnya mencapai kriteria nilai ketuntasan minimal (KKM) yakni 70 dan pada kenyataannya hanya mencapai 60, sehingga masih banyak siswa yang belum memenuhi Kriteria Ketuntasan Minimal (KKM) dalam hasil pembelajaran menulis siswa kelas IV. Dari hasil pembelajaran menulis karangangan sebelumnya dikelas IV SD Negeri Dadapsari yang berjumlah 20 orang, sekitar 4 siswa yang memperoleh nilai di atas KKM.

Berdasarkan hasil pengamatan yang telah dilakukan, pada saat proses pembelajaran dan penyebab rendahnya keterampilan menulis siswa khususnya menulis karangan deskripsi disebabkan oleh beberapa faktor diantaranya (1) kurangnya pembiasaan terhadap tradisi menulis menyebabkan siswa menjadi terbebani apabila mendapatkan tugas untuk menulis, (2) sebagian siswa membutuhkan waktu yang cukup lama untuk dapat menuangkan ide dan gagasannya, (3) siswa belum mampu dalam menuangkan ide/gagasan dengan baik, (4) siswa kurang bisa mengembangkan bahasa. Selama ini dalam pembelajaran guru menggunakan metode ceramah dan penugasan, akibatnya berdampak pada kurang optimalnya aktivitas belajar siswa. Guru merupakan ujung tombak dalam dunia pendidikan, seharusnya mampu melakukan upaya untuk mengatasi masalah ini. Salah satu langkah yang dapat dilakukan antara lain dengan menerapkan metode inovatif.

Berdasarkan data yang diperoleh dari hasil wawancara menyatakan bahwa, pembelajaran Bahasa Indonesia khususnya materi keterampilan menulis karangan deskripsi selama ini lebih banyak menggunakan metode ceramah. Pembelajaran dengan metode ceramah selama ini menjadikan siswa untuk duduk, diam, mendengarkan, mencatat, dan menghafalkan materi yang diberikan, akibatnya kegiatan pembelajaran menjadi monoton dan kurang menarik perhatian. Media yang digunakan oleh guru kurang menarik, padahal dengan menggunakan media yang menarik akan memudahkan peserta didik untuk memahami maksud dari materi yang akan disampaikan. Dapat dikatakan juga selama ini guru dalam proses pembelajaran kurang memperhatikan metode yang sesuai dengan materi yang diajarkan khusnya dalam pembelajaran keterampilan menulis karangan deskripsi.

Penggunaan metode yang tepat agar dapat memperbaiki dan meningkatkan keterampilan siswa, selain itu cara mengajar guru harus menggunakan teknik pembelajaran yang bervariasi dan kreatif. Merujuk pada segala masalah di atas, peneliti membuat berbagai solusi dalam pembelajaran menulis salah satunya pada penggunaan metode. Metode pembelajaran yang sesuai dengan karakteristik siswa dan lingkungan sekitar. Salah satu metode pembelajaran yang dapat digunakan untuk menunjang keberhasilan siswa dalam meningkatkan keterampilan menulis karangan deskripsi yaitu metode pembelajaran Field Trip. Metode field trip merupakan perjalanan yang digunakan oleh para peserta didik untuk melengkapi pengalaman belajar dan merupakan bagian integral dari kurikulum sekolah, (Sagala, 2014). Dengan mendekatkan objek belajar dengan siswa, metode field trip akan memudahkan siswa untuk menuangkan ide- ide kedalam tulisan serta dapat merangsang kreasi dan imajinasi siswa agar dapat menuangkan segala ide, pikiran, maupun gagasannya ke dalam bentuk karangan deskripsi, pengalaman belajar diluar kelas dapat dilakukan oleh siswa melalui interaksi antara siswa dengan objek/sumber belajar, sesuai dengan uraian materi pembelajaran yang telah dirumuskan sehingga siswa mudah mengingatkan materi yang telah dipelajari. Selain itu, proses 
belajar mengajar akan terasa lebih hidup dan lebih menyenangkan dibandingkan dengan melakukan proses belajar mengajar di dalam kelas.

Metode field trip merupakan perjalanan yang digunakan oleh para peserta didik untuk melengkapi pengalaman belajar dan merupakan bagian integral dari kurikulum sekolah, (Sagala, 2014). Dengan field trip sebagai metode belajar mengajar anak didik di bawah bimbingan guru mengunjungi tempat-tempat tertentu dengan maksud untuk belajar. Hal ini diperkirakan untuk meningkatkan pembelajaran menulis karangan deskripsi karena dengan mendekatkan objek belajar dengan siswa akan lebih memudahkan siswa untuk menuangkan ide-ide ke dalam tulisan. Selain itu dengan metode ini akan membuat siswa lebih nyaman dan senang ketika pembelajaran. Dengan metode ini siswa mendapat gambaran secara konkrit mengenai hal-hal yang akan ditulis, antara lain dalam menentukan topik karangan deskripsi. Dengan digunakannya metode field trip untuk membuat karangan deskripsi, diharapkan siswa dapat termotivasi untuk mengembangkan imajinasi dalam menuangkan ide, pikiran dan gagasan sesuai dengan keadaan nyata di lingkungan sekitar ke dalam bentuk tulisan.

\section{METODE PENELITIAN}

Jenis penelitian yang digunakan dalam penelitian ini adalah Penelitian Tindakan Kelas (PTK) atau dengan istilah Classroom Research (CAR). . Menurut Suharjono (2017: 58) menyatakan bahwa penelitian tindakan kelas adalah penelitian tindakan yang dilakukan dikelas dengan tujuan memperbaiki/ meningkatkan mutu praktik pembelajaran. Desain penelitian yang digunkan dalam penelitian ini adalah menggunakan model penelitian tindakan kelas Kemmis dan Mc Taggart (Arikunto, 2013: 138) yang teridir dari dua siklus dengan empat kali pertemuan pembelajaran yang di setiap siklusnya teridir dari perencanaan, pelaksanaan, pengamatan dan refleksi. Di setiap siklusnya dilaksanakan 1-2 kali pertemuan pembelajaran. Penelitian ini dilaksanakan di SD Negeri Dadapsari yang beralamat di Jl. Dadap, Gayamharjo Prambanan Sleman. Penelitian dilaksanakan pada bulan Mei 2018 pada siswa kelas IV. Subjek penelitian tindakan kelas ini adalah seluruh siswa kelas IV SD Negeri Dadapsari Sleman tahun ajaran 2017/2018. Dengan jumlah 20 siswa terdiri dari 12 siswa perempuan dan 8 siswa laki-laki. Teknik pengumpulan data adalah cara yang digunakan dalam penelitian untuk mendapatkan data. Penelitian ini menggunakan teknik pengumpulan data sebagai berikut: tes, observasi dan dokumentasi.

Penelitian ini menggunakan teknik pengumpulan data berupa observasi dan tes dengan menggunakan instrumen berupa lembar observasi dan hasil tes yang digunakan untuk mengumpulkan data. Data yang diperoleh dianalisi menggunakan metode deskriptif kuantitatif. Pada penelitian ini, analisis hasil pengamatan (observasi) kegiatan pembelajaran siswa menggunakan skala Guttman. Pengamatan selanjutnya dilakukan seperti pada skala Likert. Indikator keberhasilan siswa melalui hasil pretest dan posttest. Penelitian ini adalah peningkatan menulis karangan deskripsi dapat dikatakan berhasil apabila sesuai dengan kriteria penilaian menulis karangan deskripsi, dengan presentasi siswa yang tuntas di atas KKM (70) sebanyak $70 \%$.

\section{HASIL DAN PEMBAHASAN}

Pelaksanaan Penelitian Tindakan Kelas (PTK) yang berjudul "Peningkatan Menulis Karangan Deskripsi Menggunakan Metode Field Trip Pada Mata Pelajaran Bahasa Indonesia Siswa Kelas IV SD Negeri Dadapsari" telah selesai dilaksanakan pada bulan Mei 2018. Peroses pengambilan data dalam penelitian ini dilakukan menggunakan Metode Field Trip pada mata pelajaran Bahasa Indonesia. Materi yang digunakan dalam penelitian diambil berdasarkan Standar Kompetensi yaitu menyusun karangan tentang berbagai topik sederhana dengan memperhatikan penggunaan tanda baca. Pelaksanaan penelitian ini 
menggunakan metode Field Trip yang dilaksanakan dalam 2 siklus, masing- masing siklus terdiri dari 2 pertemuan. Dari hasil penelitian didapati bahwa aktivitas siswa mengalami peningkatan begitu juga pada hasil tes yang diberikan pada siswa juga mengalami peningkatan. Berdasarkan hasil observasi siswa yang dilakukan selama proses pembelajaran dengan menggunakan metode field trip di kelas IV. Berikut dapat dilihat perbandingan hasil observasi siswa yang dilakukan mulai dari siklus I dan siklus II pertemuan I, dan siklus I pertemuam II pada tabel dibawah ini:

Tabel 1. Hasil Observasi Siswa Siklus I

Tabel 4 Hasil Kemampuan Menulis Karangan Deskripsi Siklus I \& II Pertemuan I dan Pertemuan II

\begin{tabular}{|c|c|c|c|c|c|}
\hline & & & Siklus I & Siklus 2 & \\
\hline No & Indikator & $\begin{array}{c}\text { Hasil } \\
\text { Pertemuan } \\
1\end{array}$ & $\begin{array}{c}\text { Hasil } \\
\text { Pertemuan } \\
2\end{array}$ & $\begin{array}{c}\text { Hasil } \\
\text { Pertemuan } \\
1\end{array}$ & $\begin{array}{c}\text { Hasil } \\
\text { Pertemuan } \\
\quad 2\end{array}$ \\
\hline 1. & Inisiatif siswa dalam belajar & $\begin{array}{l}\text { Kurang } \\
\text { Baik }\end{array}$ & $\begin{array}{l}\text { Cukup } \\
\text { Baik }\end{array}$ & Baik & $\begin{array}{c}\text { Sangat } \\
\text { Baik }\end{array}$ \\
\hline 2. & $\begin{array}{l}\text { Kecenderungan siswa } \\
\text { melakukan aktifitas belajar }\end{array}$ & $\begin{array}{l}\text { Kurang } \\
\text { Baik }\end{array}$ & $\begin{array}{l}\text { Cukup } \\
\text { Baik }\end{array}$ & Baik & $\begin{array}{l}\text { Sangat } \\
\text { Baik }\end{array}$ \\
\hline 3. & $\begin{array}{l}\text { Ketertarikan siswa dalam } \\
\text { belajar }\end{array}$ & $\begin{array}{l}\text { Cukup } \\
\text { Baik }\end{array}$ & $\begin{array}{l}\text { Cukup } \\
\text { Baik }\end{array}$ & Baik & $\begin{array}{c}\text { Sangat } \\
\text { Baik }\end{array}$ \\
\hline 4. & $\begin{array}{l}\text { Semangat dan rasa senang } \\
\text { dalam belajar }\end{array}$ & $\begin{array}{l}\text { Cukup } \\
\text { Baik }\end{array}$ & $\begin{array}{l}\text { Cukup } \\
\text { Baik }\end{array}$ & $\begin{array}{l}\text { Sangat } \\
\text { Baik }\end{array}$ & $\begin{array}{l}\text { Sangat } \\
\text { Baik }\end{array}$ \\
\hline
\end{tabular}

\begin{tabular}{lcccc}
\hline \multicolumn{1}{c}{ Keterangan } & $\begin{array}{c}\text { Pertemuan } \\
\text { I }\end{array}$ & $\begin{array}{c}\text { Pertemuan } \\
\text { II }\end{array}$ & $\begin{array}{c}\text { Pertemuan } \\
\text { I }\end{array}$ & $\begin{array}{c}\text { Pertemuan } \\
\text { II }\end{array}$ \\
\hline Jumlah Siswa & 20 & 20 & 20 & 20 \\
\hline Rata-Rata Kelas & 61,4 & 69,45 & 73,5 & 76,6 \\
\hline Nilai Tertinggi & 71 & 75 & 80 & 85 \\
\hline Nilai Terendah & 55 & 64 & 68 & 69 \\
\hline Siswa Tuntas & $5(25 \%)$ & $8(40 \%)$ & $14(70 \%)$ & $18(90 \%)$ \\
\hline Siswa Tidak Tuntas & 15 & 12 & 6 & 2 \\
\hline
\end{tabular}

Penelitian Tindakan Kelas (PTK) yang telah dilaksanakan dengan menggunakan Metode Field Trip pada mata pelajaran Bahasa Indonesia kela IV SD Negeri Dadapsari Sleman yang terdiri dari II siklus dan setiap siklusnya terdiri dari 2 pertemuan menunjukkan adanya peningkatan pada kemampuan menulis karangan deskripsi sesuai dengan indikator keberhasilan yang telah ditentukan. Presentase nilai tuntas diperoleh hasil pada siklus I pertemuan pertama $25 \%$, pada siklus I pertemuan kedua menjadi $40 \%$, pada siklus II pertemuan pertama menjadi $70 \%$ dan pada siklus II pertemuan kedua menjadi 90\%. Dari hasil presentase kelas tindakan dikatakan berhasil karena telah mencapai nilai ketuntasan $>70 \%$ yaitu presentase rata-rata kelas mencapai 76,6. Darihasil tersebut dapat dikatakan bahwa hasil karangan menulis deskripsi siswa mengalami peningkatan mulai dari siklus I pertemuan pertama dan kedua sampai pada siklus II pertemuan pertama dan kedua. Untuk lebih jelasnya peningkatan presentase ketuntasan dapat dilihat dari grafik dibawah Berdasarkan hasil tersebut, secara keseluruhan tujuan penelitian tindakan kelas dengan menggunakan Metode Field Trip telah tercapai pada siklus II, sehingga penelitian dianggap sudah berhasil dan selesai 
pada siklus II. Hasil penelitian menunjukkan adanya peningkatan kemampuan siswa dalam menulis karangan deskripsi. Hasil tersebut dapat dilihat dari peningkatan disetiap siklus dalam penelitian ini. Maka dapat disimpulkan bahwa penerapan Metode Field Trip dapat meningkatkan kemampuan menulis karang deskripsi siswa kelas IV SD Negeri Dadapsari Sleman.

Hasil ini sesuai dengan penelitian sebelumnya yaitu penelitian yang dilakukan Rizkia Kurnia Rahmawati (2015) bahwa metode Field Trip dapat meningkatkan hasil belajar siswa ditandai dengan meningkatnya presentase siswa yang mencapai nilai KKM, dan seluruh siswa terlibat langsung dalam pembelajaran dengan menggunakan metode Field Trip dalam proses pembelajaran. Sedangkan hasil penelitian Wahyu Utami Riyadi (2017) menunjukkan peningkatan dengan menggunakan metode Field Trip di karenakan hasil belajar keterampilan berbicara siswa meningkat, di karenakan siswa mampu menyelesaikan permasalahan yang berhubungan dengan materi yang diajarkan. Dari data yang diperoleh menunjukkan terjadinya peningkatan. Dengan demikian pembelajaran dengan mengguanakn metode Field Trip telah berhasil dalam meningkatkan hasil belajar siswa.

\section{SIMPULAN}

Berdasarkan penelitian yang dilakukan dan berdasarkan analisis data serta pembahasan hasil penelitian yang dilakukan selama sisklus II pada siswa kelas IV SD Negeri Dadapsari dapat di simpulkan sebagai berikut: Metode Field Trip dapat meningkatkan kemampuan menulis karangan deskripsi siswa, dapat terlihat dari hasil menulis karangan siswa yang dilakukan pada mata pelajaran Bahasa Indonesia kelas IV dengan hasil persentase ketuntasan pada siklus I pertemuan I diperoleh hasil sebesar $25 \%$, pertemuan II ketuntasan sebesar $40 \%$. Pada siklus II pertemuan I persentase ketuntasan diperoleh hasil $70 \%$ dan pertemuan II diperoleh hasil $90 \%$. Dari hasil presentase rata-rata kelas tindakan dikatakan berhasil karena persentase siswa yang tuntas diatas $\mathrm{KKM}>70 \%$ terlihat pada siklus II pertemuan I dan II nilai presentase ketuntasan $70 \%$ dan $90 \%$.

Pelaksanaan tindakan dengan menggunaan metode field trip dapat meningkatkan kemampuan menulis karangan deskripsi siswa di kelas IV SD Negeri Dadapsari. Hal ini dapat di lihat dari hasil observasi pada siklus I siswa terlihat inisiatif siswa dalam belajar, kecenderungan siswa melakukan aktifitas belajar, ketertarikan siswa dalam belajar, semangat dan rasa senang dalam belajar dengan kategori cukup baik, dalam siklus II mengalami peningkatan inisiatif siswa dalam belajaran, kecenderungan siswa melakukan aktifitas belajar, ketertarikan siswa dalam belajar, semangat dan rasa senang dalam belajar dengan kategori sangat baik.

\section{DAFTAR PUSTAKA}

Arikunto, Suharsimi. (2013). Prosedur Suatu Pendekatan Praktik. Jakarta: Rineka Cipta. Nurjamal, Daeng. DKK. (2014). Terampil Berbahasa. Bandung: Alfabeta.

Sagala, Syaiful. (2014). Konsep dan Makna Pembelajaran. Bandung: Alfabeta.

Sudjiono.(2007). Pengantar Statistika Pendidikan. Jakarta : Grafindo.

Suharjono. (2015). Penelitian Tindakan Kelas. Jakarta : Bumi Aksara.

Widoyoko, S. E. P. (2015). Teknik Penyusunan Instrumen Penelitian. Jakarta: Pustaka Pelajar. 